\title{
Role of Social Relations of Outside Directors with CEO in Earnings Management
}

\author{
Muhammad Shaique ${ }^{1, *}$, Fei Guo ${ }^{1}$, Ruqia Shaikh ${ }^{1}$, Shahbaz Khan ${ }^{2}$ and Muhammad Usman ${ }^{2}$ \\ 1 School of Accounting, Zhongnan University of Economics and Law, Wuhan 430073, China; \\ fei_guo@zuel.edu.cn (F.G.); ruqia111@outlook.com (R.S.) \\ 2 School of Finance, Zhongnan University of Economics and Law, Wuhan 430073, China; \\ shahbaz.khans@yahoo.com (S.K.); usmanzuel@yahoo.com (M.U.) \\ * Correspondence: shaiq33@live.com; Tel.: +86-131-6320-0046
}

Academic Editor: Nicholas Apergis

Received: 10 April 2017; Accepted: 8 December 2017; Published: 16 December 2017

\begin{abstract}
The purpose of this study is to examine the impact of social relations among the board members on earnings management in Pakistani listed companies. Specifically, we have analyzed the social networks between CEO and outside board members. The modified Jones model has been used in this study to measure earnings management and we have captured social relations through SOCIAL (Social networking index). Our results suggest that firms with more connected boards show a positive relationship between board independence and earnings management. Further, we have shown that firms with CEO duality exhibit a higher association between social connections of the board and earnings management than firms with non-duality. Social relations among the board members undermine monitoring ability of outside directors and the impact becomes more severe in the presence of CEO duality.
\end{abstract}

Keywords: social relations; earnings management; CEO duality; outside directors

JEL Classification: M41; M48

\section{Introduction}

In this study, we have analyzed the effect of social relations between outside directors and CEO on earnings manipulation. In line with previous studies (Hwang and Kim 2010), we define social relations as non-familial relations. These relationships develop from present and previous employment and education. These kinds of relationships among the board of directors and top management weaken the corporate governance mechanism of the company and lead to corporate inefficiency (Dey and Liu 2010; Fracassi and Tate 2012; Hwang and Kim 2009; Hwang and Kim 2010; Schmidt 2015; Westphal and Graebner 2010). In our research, we have also incorporated the impact of CEO duality on earnings management because prior research shows that CEO duality has an effect on earnings management (Klein 2002) and networking within the board (Fracassi and Tate 2012). As separation of CEO and chairman of the board was not mandatory in Pakistan until 2012, a dual role of CEO and Chairman was prevalent in listed companies; thereby, a CEO's position was more powerful. For example, Fracassi and Tate (2012) suggested that powerful CEOs prioritize board members from their own social network and provide them access to inside information, which ultimately hinders an effective monitoring process (Jensen 1993).

The motivation of this research is derived from the following reasons:

(1) CEOs with social ties may undermine the independence of the board in order to gain personal benefit (i.e., compensation plan \& tenure extension) and implement CEO friendly policies. The board 
is responsible for monitoring the CEO's decisions but a board with social ties may be reluctant to act against CEO interests (Krishnan et al. 2011).

(2) Previous literature pointed out that social networks among board members and CEOs weaken the monitoring system, even if they are independent, according to the definition provided by the regulators (Dey and Liu 2010; Fracassi and Tate 2012; Hwang and Kim 2010; Schmidt 2015; Westphal and Graebner 2010).

(3) The absence of guidelines covering social connections among board members in the "Code of Corporate Governance in Pakistan".

(4) The existence of powerful CEOs (CEO duality) in Pakistani listed companies.

Accounting numbers are used to measure the firm performance, and these numbers are very important because they convey information related to current and future inflows and outflows of the firms to the existing and potential investors. However, accounting standards (IAS and IFRS) allow managers to use their discretion in the calculation of accounting earnings, such as estimation of bad debts and depreciation. Managers can use their discretion for exaggeration of the accounting numbers in order to deceive investors and creditors about a firm's performance.

Agency theory (Jensen and Meckling 1979) posits the presence of possible conflicts of interest between management objectives and stockholders' objectives, which could incentivize management to track their own goals dissimilar to the shareholders' goals. Managers have access to inside information that could be utilized for their own benefits (Easley and O'hara 2004), so they might be involved in manipulation of information for their own motives such as increasing managerial compensation, avoiding violation of debt covenants and technical default, influencing investors' expectations, and reducing the cost of capital.

'Earnings management occurs when managers use judgment in financial reporting and in structuring transactions to alter financial reports to either mislead some stakeholders about the underlying economic performance of the company or to influence contractual outcomes that depend on reported accounting numbers' (Healy and Wahlen 1999).

The debate on earnings management has been the center of attention in recent years for researchers and regulators in the context of financial accounting and management and is usually linked with corporate governance mechanisms (Chen et al. 2010; Cornett et al. 2008; Feldmann and Schwarzkopf 2003; Jaggi and Tsui 2007; Uadiale 2012; Wei 2007) and family firms (Jiraporn and DaDalt 2009; Lim et al. 2014; Villalonga and Amit 2010). In addition, board independence is one of the major characteristics of corporate governance that plays a vital role in monitoring and improving the quality of financial reporting (Carcello and Neal 2000, 2003; Klein 2002; Krishnan 2005). On the one hand, outside directors on the board are key to effective monitoring mechanisms and play an important role in constraining these opportunistic behaviors of management (Klein 2002). On the other hand, directors, who have social-ties with the CEO, may work on the board as outside directors but might not improve the monitoring, instead place more importance on their social-ties (Fracassi and Tate 2012).

It is still unclear which characteristics measure the real independence of directors (Hwang and Kim 2010). Therefore, this study is an attempt to focus on one of the most important characteristics, i.e., social connections between CEOs and outside directors that seem to undermine board independence. Moreover, social relationships among the team/board members play important roles in creating and maintaining the normative expectations in the team/board (Mills and Clark 1982; Uzzi 1996). Therefore, these relationships might be used by CEOs to influence the decision and undermine the real independence of the board. Similarly, Krishnan et al. (2011) highlighted in their study that preexistence of social relationships of a CEO with independent directors weakens the ability of independent directors to question his/her decisions, intentionally or unintentionally.

Sarbenes Oxley Act identified a CEO as one of the key positions to ensure the reliability and objectivity of financial statements. On one hand, a CEO as part of management is responsible for maintaining the transparency in the financial statement, and the board of directors are supposed to monitor the decisions of the management including the CEO. On the other hand, social relations of a 
CEO with board members did not catch the attention of previous researchers and regulators have not developed formal guidelines in this regard such as a "code of corporate governance" (Hwang and Kim 2010). These social relations can influence the transparency of accounting records and undermine the monitoring of independent directors. Fracassi and Tate (2012) showed that social connections reduce a firm's value in the absence of other governance mechanism, such as investor protection and weak law enforcement. In Pakistan, other governance mechanisms are either weak or virtually non-existent (Ashraf and Ghani 2005). Similarly, Leuz et al. (2003) clustered the countries according to their institutional settings in the study, where Pakistan was ranked in the third cluster (insider economies).

These settings and characteristics of Pakistan provide an ideal environment to conduct a study on board monitoring mechanisms and earnings management in the context of social-ties between a CEO and outside directors.

Hwang and Kim (2010) and Krishnan et al. (2011) analyzed the link between social relationships of directors with CEOs and suggested that these relationships increased the likelihood of earnings management. But prior work is mostly focused on the western part of the world. Fan and Wong (2002) suggested that studies conducted in developed economies could not be generalized to developing economies because ownership structure and institutional settings are different from developed parts of the world.

Our results make significant contributions to the existing research on socially connected boards and costs of these social relationships for corporate governance. Specifically, we have shown that socially connected directors are positively related with earnings management and the relationship becomes more prominent in the presence of CEO duality. Our research also provides new evidence on the effectiveness of independent directors in the presence of social relationships with CEOs. Our findings suggest that independent directors are unable to constrain the earnings management activities in the presence of a social relationship with a CEO. As a result, a regulatory authority (such as Securities Exchange Commission Pakistan) can incorporate guidelines related to social relationship in the ongoing reform of corporate governance. The findings of the study make an important contribution to the literature of corporate governance from the perspective of independent directors. We add further evidence to previous literature on CEO affiliations by analyzing social affiliation, similar to previous researchers that have analyzed political affiliation (Cheema et al. 2016; Li et al. 2016) and familial affiliations (Chi et al. 2015).

The remainder of the paper is organized as follows: In the later part, we have reviewed the literature and develop hypotheses. Then, we have discussed our research design. In the last section, we have explained the results and have drawn conclusions.

\section{Review of Literature and Research Hypothesis}

\subsection{Board Monitoring Mechanism and Earnings Management}

In most of the developing countries, external governance mechanisms are not effective and efficient and consequently, more focus is placed on the internal governance mechanism (Young et al. 2008). For the listed companies, the board of directors is perceived to be a crucial part of the internal monitoring mechanism and is responsible for overseeing the managements' opportunistic actions. Particularly, independence of a board is a fundamental component of constraint earnings management, as a board comprising more outside directors can provide more independence, competency, and experience to the firm. Therefore, the code of corporate governance of Pakistan requires all listed companies to acquire independent directors with essential knowledge, skills, and experience (Securities and Exchange Commission of Pakistan 2012). These characteristics strengthen the board monitoring over management and its opportunistic behavior. For instance, Cornett et al. (2009) concluded in their study that outside directors deter management from opportunistic behavior. Similarly, independence in the board is key to effective monitoring of the financial reporting process (Klein 2002). Furthermore, Beasley (1996) argued that there is less probability of financial fraud in firms where more outside 
directors are on the board. The likelihood of engaging in financial fraud is lower in firms with boards having more independent directors (Agrawal and Chadha 2005).

Monitoring Effects of Board Independence in the Presence of Social Relationships

According to the governance theory, a board of the directors is representative of shareholders to monitor the decisions of management. Board independence leads to a smooth flow of information among all the channels of the company, increasing the credibility of information, keeping proper checks and balances on management, decreasing the probability of fraud (Agrawal and Chadha 2005; Beasley 1996) and, increasing the quality of disclosure (Chen and Jaggi 2001). These things create a positive image for the company in the minds of investors. Board independence with respect to management is important for monitoring and controlling management's action (Krishnan et al. 2011). On the contrary, if the outside director is not independent from management, he/she might fail to perform unbiased monitoring. For example, Fracassi and Tate (2012) pointed out that a director, who had social relations with a CEO, might work on the board as an outside director or so-called independent director (not really independent). According to (Dechow et al. 1996), firms with greater dominance of management on the board are more susceptible to financial fraud. However, network ties also appeared to weaken corporate governance, leading to distortions in director's selection (Kuhnen 2009), CEO retention decisions (Nguyen 2012), and corporate investment (Guner et al. 2008). Hallock (1997) found positive correlations between CEO compensation and the fact that a firm had an interlocking relationship with another firm. In addition, several recent papers argued that network connections through cross-directorships led to higher executive compensation (Guedj and Barnea 2009; Hwang and Kim 2009; Larcker et al. 2005). In addition, CEO/CFO social ties with outside directors (Krishnan et al. 2011) and CEO social ties with audit committees increase earnings management (Hwang and Kim 2010). From the existing literature, it can be observed that social relations of the directors with CEOs may affect the monitoring ability of independent directors. In light of the above-mentioned discussion, we hypothesize that:

Hypothesis 1. Existence of social connections among the board members with a CEO undermines the relationship between board independence and earnings management.

\subsection{Dual Structure of a CEO and Chairman of the Board}

According to agency theory, the chairman of the board should be independent from any executive role in the management. The dual structure of a CEO/Chairman allows a CEO to obtain available information from inside the board that ultimately hinders effective monitoring (Jensen 1993). Klein (2002) conducted a study on U.S. companies using a sample of 687 firms and calculated aggregate accruals through Jones' model (Jones 1991). The results of his study showed the positive relation between CEO duality and earnings management. Similarly, Cornett et al. (2008) suggested that the separate role of a CEO and Chairman of the board provides more efficient monitoring.

The code of corporate governance in Pakistan did not require the separation of chairman of the board and Chief Executive Officer (CEO) until 2012 (Securities and Exchange Commission of Pakistan 2012), which may have led to a power concentration of a CEO to deal with business activities and managerial decisions. A socially connected CEO with the board of directors may influence the decision of the board and involve opportunistic behaviors, such as Larcker et al. (2005) suggested that the "back door" distance between a CEO and the chair of his/her compensation committee and found that closer connections between the CEO and the chair of the compensation committee result in higher CEO compensation. In addition, Hwang and Kim (2010) conducted a study on social ties between CEOs and the board of directors, who are also a part of the audit committee and suggested that these social ties increase the earnings management activities. Furthermore, the dual power of a CEO increases the magnitude of the influence on the board decisions. Zajac and Westphal (1996) found evidence that firms in which the CEO had more control over the director selection process are more likely to add directors having a history of implementing CEO-friendly policies. Similarly, Fracassi and Tate 
(2012) showed that dominant CEOs hire directors from their pre-existent relationships. In light of the aforementioned discussion based on previous studies, we expect that social connections of CEO with a board of directors will have more severe impact on earnings management in the presence of CEO duality. Hence, we hypothesize that

Hypothesis 2. The impact of CEO-board social relations on earnings management will be higher in the presence of CEO duality.

\section{Research Design}

For analyzing hypothesis one, we have used Equation (1) and divided our total sample into two sub samples based on the score of Social Networking Index (SOCIAL, hereafter). Sub sample one includes only those firms whose individual SOCIAL score is more than the mean of the total sample and are labelled as "connected-board". Sub-sample two includes only those firms whose SOCIAL score is less than the mean of the total sample and are labelled as "non-connected-board". We use Equation (1) for two sub-samples "connected-board" and "non-connected-board" and the results support the hypothesis of this study

$$
\mathrm{EM}_{\mathrm{it}}=\beta_{0}+\beta_{1} \mathrm{BIND}_{\mathrm{it}}+\beta_{2} \mathrm{CFO}_{\mathrm{it}}+\beta_{3} \mathrm{SIZE}_{\mathrm{it}}+\beta_{4} \mathrm{LEVERAGE}_{\mathrm{it}}+\varepsilon_{\mathrm{it}}
$$

For analyzing hypothesis two, we have used Equation (2) and divided our sample into two sub-samples based on the existence of CEO duality in the firms. Sub-sample one includes only those firms in which CEO duality exists and are labelled as "dual". Sub-sample two include firms in which CEO duality does not exist and are labelled as "Non-dual". We use Equation (2) for both subsample and the findings support our hypothesis.

$$
\mathrm{EM}_{\mathrm{it}}=\beta_{0}+\beta_{1} \text { SOCIAL }_{\mathrm{it}}+\beta_{2} \mathrm{CFO}_{\mathrm{it}}+\beta_{3} \text { SIZE }_{\mathrm{it}}+\beta_{4} \text { LEVERAGE }_{\mathrm{it}}+\varepsilon_{\mathrm{it}}
$$

\subsection{Measurement of Earnings Management}

Total accruals have become the most commonly used proxy in academic accounting for capturing the earnings manipulation (Dechow et al. 1995). Total accruals include non-discretionary -and discretionary accruals: those accruals which only can be determined by economic conditions of a firm are considered as non-discretionary accruals. Discretionary accruals represent earnings manipulation and these accruals are usually used by managers to achieve the earnings target artificially. In short, managers use their discretionary power in the selection of different accounting methods for manipulation of the earnings; these practices are known as earnings management, and this point of view is backed by existing literature in the related field, for example (Bartov et al. 2000; Dechow et al. 1995; Holthausen et al. 1995; Jones 1991; Warfield et al. 1995).

As pointed out by researchers, discretionary accruals are symbolic of the managed part of accruals that is used for earnings management, which may be positive or negative, depending on the implied inspiration of firm or management, whether management wants to overstate or understate the earnings. Overstatement of earnings may be a sign of various types of inspirations, for example, to raise the stock price with deceiving intentions for issuing new shares in a secondary market or firm to try to meet or beat the analyst's forecast. On the other hand, understatement similarly leads to different underlying inspirations, particularly to stay away from the regulatory costs. Therefore, previous researchers supported the view of considering the absolute value of the abnormal part of the accruals in order to capture both motivation, either overstatement or understatement of the earnings (Becker et al. 1998; Jiambalvo et al. 2002; Warfield et al. 1995). As Pakistan is not an exception, the firms in Pakistan may have both inspirations so the value may be negative or positive on the basis of the implied motivations of every firm.

Model for Capturing Earnings Management 
Various accruals models are used to estimate the earnings management models, as suggested by a variety of researchers in their studies, for example (DeAngelo 1986; Dechow et al. 1995; Healy 1985; Jones 1991; Kothari et al. 2005). Among all the mentioned models, prior studies considered that the Jones Model 1991 and the modified Jones Model Dechow 1995 are more dominant for capturing earnings management. We used the modified Jones model to measure the earnings management for our main analysis and we have also used the Jones model for our robustness analysis in the Appendix A.

$$
\begin{gathered}
\frac{\mathrm{TA}_{\mathrm{it}}}{\mathrm{A}_{\mathrm{it}-1}}=\alpha_{1}\left(\frac{1}{\mathrm{~A}_{\mathrm{it}-1}}\right)+\alpha_{2}\left(\frac{\Delta \mathrm{REV}_{\mathrm{it}}}{\mathrm{A}_{\mathrm{it}-1}}\right)+\alpha_{3}\left(\frac{\mathrm{PPE}_{\mathrm{it}}}{\mathrm{A}_{\mathrm{it}-1}}\right)+\varepsilon_{\mathrm{it}} \\
\mathrm{DA}_{\mathrm{it}}=\frac{\mathrm{TA}_{\mathrm{it}}}{\mathrm{A}_{\mathrm{it}-1}}-\left[\hat{\mathrm{a}}_{1}\left(\frac{1}{\mathrm{AT}_{\mathrm{it}-1}}\right)+\hat{\mathrm{a}}_{2}\left(\frac{\Delta \mathrm{REV}_{\mathrm{it}}-\Delta \mathrm{AR}_{\mathrm{it}}}{\mathrm{AT}}\right)+\hat{\mathrm{a}}_{3}\left(\frac{\mathrm{PPE}_{\mathrm{it}}-1}{\mathrm{AT}_{\mathrm{it}-1}}\right)\right]
\end{gathered}
$$

where $\mathrm{TA}_{\mathrm{it}}($ Total Accrual $)=$ Net income $_{\text {it }}$ (earnings before extraordinary items and discontinued operations) - Cash Flow $i$ for firm i in the year t; $\mathrm{DA}_{i t}$ (Discretionary Accrual) $=$ Total accrual Normal Accrual; $\Delta \mathrm{REV}_{\mathrm{it}}=$ Change in net revenue (Sales) for firm $\mathrm{i}$ in the year $\mathrm{t} ; \Delta \mathrm{AR}_{\mathrm{it}}=$ Change in accounts receivable for firm $i$ in the year $\mathrm{t} ; \mathrm{A}_{\mathrm{it}-1}=$ Total assets for firm $\mathrm{i}$ in the year $\mathrm{t} ; \varepsilon_{\mathrm{it}}=$ Error term for firm $i$ in year $t$.

\subsection{Measurement of Social Networking Index (SOCIAL)}

To measure social relationships of outside directors with a CEO, we observed their current employment (designation, organization and corporate boards on which they serve), previous employment (organization, designation, and number of years they served), and educational background (institutions, degrees and years of study). We followed Fracassi and Tate (2012) in the calculation of SOCIAL. The scores are calculated as 0 and 1 . If the CEO and outside director are currently serving on the board of any other organization the score will be 1 , otherwise 0 . If the outside director and CEO have served together in the past, the score will be 1, otherwise 0 . If the CEO and outside directors have any academic connection, the score will be 1 , otherwise 0 . All three scores are accumulated for all the directors and divided by the number of outside directors to obtain the average social networking score for each company. The average score is considered to avoid any kind of bias. Then, the mean is calculated to classify the companies into two categories. The first category includes the companies whose score is above the mean, and the second category includes the companies whose score is below than mean. In the end, we used a dummy variable for socially connected firms and assigned 1 to those firms whose social networking score is higher than mean or 0 otherwise. See the following equation for the Social networking index:

$$
\text { SOCIAL }_{i}=\frac{\left(\mathrm{SED}_{\mathrm{i}}+\mathrm{SCE}_{\mathrm{i}}+\mathrm{SPE}_{\mathrm{i}}\right)}{\text { Total number of outside director }}
$$

In Equation (4), SOCIAL $L_{i}$ represents the SOCIAL score for firm $\mathrm{i}, \mathrm{SED}_{\mathrm{i}}$ represents education background connection of the $\mathrm{CEO}$ and outside directors of the $i^{\text {th }}$ firm, $\mathrm{SCE}_{\mathrm{i}}$ represents current employment connection of the CEO and outside directors of the $i^{\text {th }}$ firm, $\mathrm{SPE}_{\mathrm{i}}$ represents prior employment connection of the CEO and outside directors of the $\mathrm{i}^{\text {th }}$ firm, divided by the number of outside directors on the board. On the basis of the mean (1.30), the sample is divided into two parts. The first part includes companies whose SOCIAL score is higher than 1.30 and the remainder are those whose SOCIAL score is less than 1.30. The other variables used in the study are defined in Table 1. 
Table 1. Variables Definition.

\begin{tabular}{ccl}
\hline Variables & SIGN & \multicolumn{1}{c}{ Measurement } \\
\hline $\begin{array}{c}\text { Dependent Variable } \\
\text { Abnormal Accrual } \\
\text { Independent Variables }\end{array}$ & EM & Absolute abnormal accrual used as a proxy for earnings management \\
Board independence & BIND & $\begin{array}{l}\text { Total independent directors on the board divided by the total number of } \\
\text { the directors on the board. }\end{array}$ \\
$\begin{array}{c}\text { Social Networking } \\
\text { It is a dummy variable if SNI score above mean, is equal to 1, otherwise } 0 . \\
\text { Sariables }\end{array}$ & SOCIAL & Measurement \\
Size & Natural log of Total Assets \\
Cash flow Operations & Cash flow operations divided by lagged total assets \\
Leverage & LEVERAGE & Total debt over total assets \\
\hline
\end{tabular}

\subsection{Data and Sample Selection}

Our sample contains data of companies listed on the PSX (Pakistan stock exchange) for the period of four years from 2010 to 2013. The PSX (Pakistan stock exchange) is the largest stock exchange of Pakistan. The Index that is used for Karachi stock exchanges is the KSE-100 index. As described by the official website of the Pakistan stock exchange, the KSE-100 Index was constructed in November 1991 with a base value of 1000 points. This index includes the top one hundred companies and the basis for choosing those companies is sector representation and highest market capitalization. Those selected companies cover more than $90 \%$ of whole capitalization of the firms listed on the Exchange. Our sample consists of 49 non-financial companies from the KSE-100 index. The financial companies are excluded, because these companies have different governance and regulatory mechanisms. Some of the non-financial companies are also excluded because of unavailability of data for the years from 2010 to 2013. We access different sources for acquiring information on social profiles of the directors such as, annual reports and official websites of the companies.

\section{Empirical Analyses}

Table 2 summarizes the descriptive statistics of the variables used in the study. The earnings management (EM) has a mean of 0.1485 . The mean value of the proportion of outside directors (BIND) is 0.1561 , which means that on average a company has $15.61 \%$ outside directors. The mean of the social networking index (SOCIAL) is 0.6630 , which means that in $66.3 \%$ of firms, the CEOs have social connections with outside directors. The mean of the dual structure of the CEO (DUAL) is 0.4673, showing that $46.73 \%$ of firms have CEO duality.

Table 2. Descriptive Statistics.

\begin{tabular}{cccccc}
\hline Variables & Mean & Median & Std. Deviation & Max & Min \\
\hline EM & 0.1485 & 0.0982 & 0.1854 & 1.6833 & 0.0000 \\
BIND & 0.1561 & 0.1250 & 0.1577 & 0.7778 & 0.0000 \\
SOCIAL & 0.6630 & 1.0000 & 0.4739 & 1.0000 & 0.000 \\
DUAL & 0.4673 & 0.0000 & 0.5003 & 1.0000 & 0.000 \\
CFO & 0.0665 & 0.0514 & 0.1209 & 0.5456 & -0.2512 \\
SIZE & 22.8987 & 22.7379 & 1.2403 & 26.5472 & 20.4523 \\
LEVERAGE & 0.5669 & 0.5656 & 0.1911 & 1.2066 & 0.2068 \\
\hline
\end{tabular}

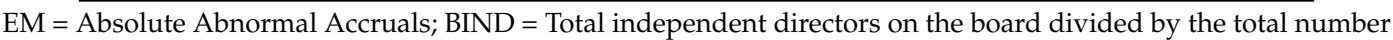
of the directors on the board; SOCIAL = It is a dummy variable if the SNI score is above the mean: is equal to 1, otherwise 0 ; DUAL = It is a dummy variable if the CEO also holds the position of Chairman of the board: is equal to 1, otherwise 0; SIZE = Natural log of Total Assets; $\mathrm{CFO}=$ Cash flow operations divided by lagged total assets; LEVERAGE $=$ Total debt over total assets.

Table 3, shows the correlation between the earnings management (EM), proportion of outside directors (BIND), CEO duality (DUAL) and other firm characteristics. Earnings management (EM) and social relations (SOCIAL) are positively related, showing that close social relations lead to higher 
earnings management. Proportion of outside director (BIND) is also positively correlated with earnings management (EM).

Table 3. Correlations among Variables.

\begin{tabular}{cccccccc}
\hline Variables & EM & SOCIAL & DUAL & CFO & SIZE & LEVERAGE & BIND \\
\hline EM & 1.0000 & & & & & & \\
SOCIAL & 0.3596 & 1.0000 & & & & & \\
DUAL & 0.3540 & 0.3452 & 1.0000 & & & & \\
CFO & -0.1010 & -0.0947 & -0.2061 & 1.0000 & & & \\
SIZE & 0.1776 & 0.0435 & 0.0329 & -0.0049 & 1.0000 & & \\
LEVERAGE & -0.2320 & -0.0399 & -0.2546 & -0.1458 & 0.0312 & 1.0000 & \\
BIND & 0.1691 & 0.0621 & 0.2138 & 0.0673 & 0.0439 & 0.0342 & 1.0000 \\
\hline
\end{tabular}

$\mathrm{EM}=$ Absolute Abnormal Accruals; BIND = Total independent directors on the board divided by the total number of the directors on the board; SOCIAL = It is a dummy variable if the SNI score is above the mean: is equal to 1 , otherwise 0 ; DUAL = It is a dummy variable if the CEO also holds the position of Chairman of the board: is equal to 1 , otherwise 0 ; $\mathrm{SIZE}=$ Natural $\log$ of Total Assets; $\mathrm{CFO}=$ Cash flow operations divided by lagged total assets; LEVERAGE $=$ Total debt over total assets.

Table 4 summarizes multivariate analysis. In Model 1, board independence (BIND) shows positive and significant relationships with earnings management (see Table 4). This phenomenon can be explained by several factors such as the code of corporate governance (2012) did not mandate public companies to hire independent directors for their board, so many companies do not have independent directors on their board. The companies have independent directors on their board but they are not independent-minded. It is because of the questions raised in the previous literature that "whether independent directors are independent-minded with respect to CEOs" (Hwang and Kim 2010) or the existing formal definition of the board independence really incorporates the social ties (Krishnan et al. 2011), i.e., directors who have social-ties with CEO may work on the board as an outside director but do not improve the monitoring mechanism, rather he/she provides biased support to the CEO (Fracassi and Tate 2012). We checked the robustness of our analysis by incorporating Jones Model in Table A1 in Appendix A.

Table 4. Effects of board independence on earnings management in presence social relationships on earnings management.

\begin{tabular}{cccc}
\hline Variables & Full Sample & Connected-Boards & Non-Connected-Boards \\
\hline EM & Model 1 & Model 2 & Model 3 \\
\hline \multirow{2}{*}{ BIND } & $0.2451^{* * *}$ & $0.3539^{* * * *}$ & -0.0243 \\
& $(2.68)$ & $(3.21)$ & $(-0.18)$ \\
\hline \multirow{2}{*}{ CFO } & $-0.2922^{*}$ & -0.2438 & -0.1796 \\
& $(-1.82)$ & $(-1.38)$ & $(-0.68)$ \\
\hline \multirow{2}{*}{ SIZE } & $0.0341^{*}$ & 0.0293 & $0.0382^{* *}$ \\
& $(1.68)$ & $(1.24)$ & $(2.15)$ \\
\hline \multirow{2}{*}{ LEVERAGE } & $-0.3165^{* * *}$ & $-0.3798^{* * *}$ & $-0.2362^{* * *}$ \\
\hline \multirow{2}{*}{ Constant } & $(-3.04)$ & $(-2.5)$ & $(-2.97)$ \\
\hline R & -0.6271 & -0.4496 & $(-2.06)$ \\
\hline F-value & $(-1.46)$ & $(-0.94)$ & 0.1622 \\
\hline $\mathrm{N}$ & 0.1333 & 0.1393 & $5.47^{* * *}$ \\
\hline
\end{tabular}

$\mathrm{EM}=$ Absolute Abnormal Accruals; BIND = Total independent directors on the board divided by the total number of the directors on the board; SOCIAL = It is a dummy variable if the SNI score is above the mean: is equal to 1, otherwise 0; $\mathrm{SIZE}=$ Natural $\log$ of Total Assets; $\mathrm{CFO}=$ Cash flow operations divided by lagged total assets; LEVERAGE $=$ Total debt over total assets. ${ }^{* * *}$ Significant at $1 \%,{ }^{* *}$ Significant at $5 \%,{ }^{*}$ Significant at $10 \%$. 
In addition, social ties among directors and CEO may weaken the monitoring mechanism of corporate governance and increase the earnings management activities. In order to be more specific, we divided sub-samples on the basis of existence of social connections. In Table 4, Sub-sample 1 (Connected-boards) shows the firms in which the SOCIAL score is higher than its mean (1.30). Sub-sample 2 (Non-connected-boards) show the firms in which the SOCIAL score is less than mean (1.30). In Model 2, we only include subsample 1 (Connected-boards); we found that the relationship between (BIND) and (EM) earnings management became more intense. It suggests that the existence of social networks between CEOs and independent directors may lead to earnings management or CEOs can use discretion over the decisions more easily in the existence of social relationship. The code of corporate governance of Pakistan focuses more on financial and familial relations of independent directors with firms or management of the firm. However, social relations are not addressed in the code of corporate governance of Pakistan. It is reasonable that these informal relations can be used by CEOs to gain biased support from independent directors in board decisions. Our results are in line with previous studies, for example (Dey and Liu 2010; Fracassi and Tate 2012; Hwang and Kim 2010) and suggest that the existence of social connections among independent directors and firm's management undermine the corporate governance. In addition, model 3, which includes sub-sample 2 (Non-connected-boards), shows the negative but statistically insignificant relationship between board independence (BIND) and earnings management (EM). The sub-sample only includes the firms that have fewer social connections as compared to model 2 (Connected-boards). These results also suggest that the presence of social relations may lead to earnings management

Overall, our results suggest that outside directors fail to provide an effective role in constraining earnings management practices in the presence of social relations. Similarly, it has been acknowledged by Westphal and Graebner (2010) that social connections in board weaken the independence of directors. Further Krishnan et al. (2011) also suggest that social networks create hindrances in achieving primary objectives of corporate governance and reduce the quality of information.

In Table 5 and model 4 , the result shows positive and significant relationships between earnings management (EM) and social relations (SOCIAL). To test hypothesis two, we divided the study sample into two subsamples on the basis of CEO duality and non-duality. Sub-sample 1 includes the firms in which the CEO also has the position of chairman of the board (Dual). Sub-sample 2 shows the firms in which the CEO is not the chairman of the board (Non-dual). Particularly, in model 5, (Dual) results show a positive and highly significant relationship $\left(t=6.29^{* * *}\right)$ between $(E M)$ and (SOCIAL). These results are consistent with the notion that duality enables concentration of power and may allow a $\mathrm{CEO}$ to involve in opportunistic behavior by utilizing the social relations with outside directors. In a similar fashion, Fracassi and Tate (2012) show that firms with powerful CEOs are likely to have socially connected boards. Thus, in the presence of CEO duality the impact of social relations (SOCIAL) became more rigorous on earnings management (EM). In model 6 (Subsample 2) the relationship between $(\mathrm{EM})$ and $(\mathrm{SOCIAL})$ is positive but with less intensity $\left(\mathrm{t}=1.94^{* *}\right)$. It indicates that the existence of CEO duality intensifies the impact of social networking (SOCIAL) on earnings management (EM) compared to non CEO duality. We conducted the robustness analysis in Appendix A (Table A2), in which we incorporated the Jones 1991 model to capture the discretionary accruals and we found similar results to support our main findings. 
Table 5. Effects of social relationships on earnings management in presence of CEO duality.

\begin{tabular}{cccc}
\hline Variables & Full Sample & Dual & Non-Dual \\
\hline EM & Model 4 & Model 5 & Model 6 \\
\hline \multirow{2}{*}{ SOCIAL } & $0.1669^{* * *}$ & $0.2721^{* * *}$ & $0.0676^{*}$ \\
& $(5.84)$ & $(6.29)$ & $(1.94)$ \\
\hline \multirow{2}{*}{ CFO } & -0.2046 & 0.0789 & $-0.3112^{*}$ \\
& $(-1.34)$ & $(0.27)$ & $(-1.86)$ \\
\hline \multirow{2}{*}{ SIZE } & $0.0326^{*}$ & 0.0371 & 0.0051 \\
& $(1.70)$ & $(1.57)$ & $(0.3)$ \\
\hline \multirow{2}{*}{ LEVERAGE } & $-0.2985^{* * *}$ & $-0.3071^{*}$ & $-0.2056^{* *}$ \\
& $(-3.05)$ & $(-1.83)$ & $(-2.26)$ \\
\hline \multirow{2}{*}{ Constant } & $-0.6824^{*}$ & $-0.8434^{*}$ & -0.0821 \\
\hline $\mathrm{R}^{2}$ & $(-1.68)$ & $(-1.75)$ & $(-0.20)$ \\
\hline F-value & 0.2163 & 0.2258 & 0.1267 \\
\hline $\mathrm{N}$ & $12.83^{* * *}$ & $12.72 * * *$ & $2.722^{* *}$ \\
\hline
\end{tabular}

$\mathrm{EM}=$ Absolute Abnormal Accruals; SOCIAL = It is a dummy variable if the SOCIAL score is greater than its mean: is equal to 1 , otherwise 0 ; $\mathrm{SIZE}=$ Natural $\log$ of Total Assets; $\mathrm{CFO}=$ Cash flow operations divided by lagged total assets; LEVERAGE $=$ Total debt over total assets. ${ }^{* * *}$ Significant at $1 \%,{ }^{* *}$ Significant at $5 \%,{ }^{*}$ Significant at $10 \%$.

\section{Conclusions}

The results of our study show that firms with socially connected boards are more prone to be involved in earnings management than their counterpart firms. Social relations of outside directors with CEO may weaken the corporate governance mechanism in Pakistani listed firms. Findings of the study are in line with prior research that social relations with CEO undermine the monitoring ability of outside director (Dey and Liu 2010; Fracassi and Tate 2012) and increase the earnings management activities (Hwang and Kim 2010; Krishnan et al. 2011). Our results suggest that the director, who has a social affiliation with the CEO, might work on the board as an outside director but may not improve the monitoring mechanism. Furthermore, we find a high association between social relations and earnings management, suggesting that powerful CEOs exploit more of their social affiliation with outside directors than less powerful CEOs.

This study contributes to the literature by analyzing the impact of social relations among the outside directors and CEO on earnings management activities. We investigate CEO duality (powerful CEO) in our study that was not analyzed by previous studies. Previous researchers (Hwang and Kim 2010) were focused on social affiliation of CEO with audit committee. However, Krishnan et al. (2011) conducted a comprehensive study on social ties and earnings management and included CEO duality in control variables, but did not highlight the role of powerful CEOs. This study contributes to the literature of emerging economies with a perspective of social relations and earnings management as the area is little exploited in the developing part of the world, and prior research is more focused on the developed part of the world.

This research has a few limitations. We used a small sample size due to limited availability of biographic information about outside directors in Pakistan. Because of several cultural and institutional factors, this study can only be generalized to similar environment and institutional settings.

Author Contributions: M.S. initiated and envisioned the research, F.G. provided the supervision and expert opinion, R.S. and M.U. accomplished empirical analyses. S.K. supported in results and proofreading. All authors reviewed the results and coordinated in manuscript formulation and modification.

Conflicts of Interest: The Authors have proclaimed that they have no conflicting interest related to the contents of this paper. 


\section{Appendix A}

In this appendix, we incorporate the robustness analysis and used the Jones (1991) model for calculation of discretionary accruals. We found the similar results by using Jones (1991) to our main results. We use similar methodology for division of samples as discussed above in research design Section 3.

Table A1. Effects of board independence on earnings management in presence social relationships on earnings management.

\begin{tabular}{cccc}
\hline Variables & Full Sample & Connected-Boards & Non-Connected-Boards \\
\hline EM & Model 1 & Model 2 & Model 3 \\
\hline \multirow{2}{*}{ BIND } & $0.1228^{* *}$ & $0.3539^{* * *}$ & 0.0694 \\
& $(1.90)$ & $(3.21)$ & $(1.04)$ \\
\hline \multirow{2}{*}{ CFO } & $-0.4986^{* * *}$ & -0.2438 & $-0.6134^{* * *}$ \\
& $(-3.89)$ & $(-1.38)$ & $(-6.07)$ \\
\hline \multirow{2}{*}{ SIZE } & 0.0180 & 0.0293 & -0.0128 \\
& $(0.83)$ & $(1.24)$ & $(-1.01)$ \\
\hline \multirow{2}{*}{ LEVERAGE } & $-0.1878^{*}$ & $-0.3798^{* * *}$ & $(-2.17)$ \\
\hline \multirow{2}{*}{ Constant } & $(-1.78)$ & $(-2.5)$ & 0.3898 \\
& -0.2860 & -0.4496 & $(0.183)$ \\
\hline $\mathrm{R}^{2}$ & $(-0.64)$ & $(-0.94)$ & 0.4201 \\
\hline F-value & 0.1390 & 0.1393 & $11.94 * * *$ \\
\hline $\mathrm{N}$ & $28.16^{* * *}$ & $4.49^{* * *}$ & 62 \\
\hline
\end{tabular}

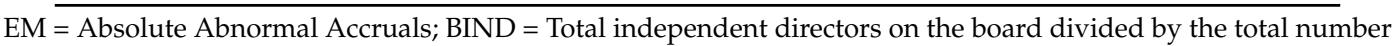
of the directors on the board; SOCIAL = It is a dummy variable if SNI score above mean, is equal to 1 , otherwise 0 ; SIZE $=$ Natural $\log$ of Total Assets; $\mathrm{CFO}=$ Cash flow operations divided by lagged total assets; LEVERAGE = Total debt over total assets. ${ }^{* * *}$ Significant at $1 \%,{ }^{* *}$ Significant at $5 \%,{ }^{*}$ Significant at $10 \%$.

Table A2. Effects of social relationships on earnings management in presence of CEO duality.

\begin{tabular}{cccc}
\hline Variables & Full Sample & Dual & Non-Dual \\
\hline EM & Model 4B & Model 5B & Model 6B \\
\hline \multirow{2}{*}{ SOCIAL } & $\begin{array}{c}0.0406^{*} \\
(1.82)\end{array}$ & $\begin{array}{c}0.099 * * \\
(2.56)\end{array}$ & $\begin{array}{c}\text { * } \\
(-0.0075)\end{array}$ \\
\hline \multirow{2}{*}{ CFO } & $-0.4721^{* * *}$ & -0.1509 & $-0.6815^{* * *}$ \\
& $(-3.36)$ & $(-0.45)$ & $(-8.76)$ \\
\hline \multirow{2}{*}{ SIZE } & 0.0180 & 0.0238 & -0.0086 \\
& $(0.83)$ & $(0.83)$ & $(-0.89)$ \\
\hline \multirow{2}{*}{ LEVERAGE } & $-0.1848^{*}$ & -0.1304 & $-0.2030 * * *$ \\
\hline \multirow{2}{*}{ Constant } & $(-1.78)$ & $(-0.65)$ & $(-3.33)$ \\
\hline $\mathrm{R}^{2}$ & -0.2975 & -0.5112 & 0.3576 \\
\hline F-value & $(-0.66)$ & $(-0.89)$ & $(1.57)$ \\
\hline $\mathrm{N}$ & 0.1388 & 0.0503 & 0.5254 \\
\hline
\end{tabular}

$\mathrm{EM}=$ Absolute Abnormal Accruals; SOCIAL = It is a dummy variable if SOCIAL score greater than its mean, is equal to 1 , otherwise 0 ; SIZE = Natural $\log$ of Total Assets; $\mathrm{CFO}=$ Cash flow operations divided by lagged total assets; LEVERAGE $=$ Total debt over total assets. ${ }^{* * *}$ Significant at $1 \%,{ }^{* *}$ Significant at $5 \%,{ }^{*}$ Significant at $10 \%$. 


\section{References}

Agrawal, Anup, and Sahiba Chadha. 2005. Corporate governance and accounting scandals. Journal of Law and Economics 48: 371-406. [CrossRef]

Ashraf, Junaid, and WaQar I. Ghani. 2005. Accounting development in Pakistan. The International Journal of Accounting 40: 175-201. [CrossRef]

Bartov, Eli, Ferdinand A. Gul, and Judy S. L. Tsui. 2000. Discretionary-accruals models and audit qualifications. Journal of Accounting and Economics 30: 421-52. [CrossRef]

Beasley, Mark S. 1996. An empirical analysis of the relation between the board of director composition and financial statement fraud. Accounting Review 71: 443-65.

Becker, Connie L., Mark L. DeFond, James Jiambalvo, and K. Subramanyam. 1998. The effect of audit quality on earnings management. Contemporary Accounting Research 15: 1-24. [CrossRef]

Carcello, Joseph V., and Terry L. Neal. 2000. Audit committee composition and auditor reporting. The Accounting Review 75: 453-67. [CrossRef]

Carcello, Joseph V., and Terry L. Neal. 2003. Audit committee characteristics and auditor dismissals following "new" going-concern reports. The Accounting Review 78: 95-117. [CrossRef]

Cheema, Moeen Umar, Rahat Munir, and Sophia Su. 2016. Political connections and organisational performance: Evidence from Pakistan. International Journal of Accounting and Information Management 24: 321-38. [CrossRef]

Chen, Charles J., and Bikki Jaggi. 2001. Association between independent non-executive directors, family control and financial disclosures in Hong Kong. Journal of Accounting and Public Policy 19: 285-310. [CrossRef]

Chen, Shaw K., Bing-Xuan Lin, Yaping Wang, and Liansheng Wu. 2010. The frequency and magnitude of earnings management: Time-series and multi-threshold comparisons. International Review of Economics \& Finance 19: 671-85.

Chi, Ching Wen, Ken Hung, Hui Wen Cheng, and Pang Tien Lieu. 2015. Family firms and earnings management in Taiwan: Influence of corporate governance. International Review of Economics \& Finance 36: 889-88.

Cornett, Marcia M., Alan J. Marcus, and Hassan Tehranian. 2008. Corporate governance and pay-for-performance: The impact of earnings management. Journal of Financial Economics 87: 357-73. [CrossRef]

Cornett, Marcia M., Jamie J. McNutt, and Hassan Tehranian. 2009. Corporate governance and earnings management at large US bank holding companies. Journal of Corporate Finance 15: 412-30. [CrossRef]

DeAngelo, Linda E. 1986. Accounting numbers as market valuation substitutes: A study of management buyouts of public stockholders. Accounting Review 61: 400-20.

Dechow, Patricia M., Richard G. Sloan, and Amy P. Sweeney. 1995. Detecting earnings management. Accounting Review 70: 193-225.

Dechow, Patricia M., Richard G. Sloan, and Amy P. Sweeney. 1996. Causes and consequences of earnings manipulation: An analysis of firms subject to enforcement actions by the SEC. Contemporary Accounting Research 13: 1-36. [CrossRef]

Dey, Aiyesha, and Xiaohui Liu. 2010. Social Connections, Stock-Based Compensation, and Director Oversight. Available online: https:/ / ssrn.com/abstract=1581212 (accessed on 28 December 2016).

Easley, David, and Maureen O'hara. 2004. Information and the cost of capital. The Journal of Finance 59: $1553-83$. [CrossRef]

Fan, Joseph P., and Tak J. Wong. 2002. Corporate ownership structure and the informativeness of accounting earnings in East Asia. Journal of Accounting and Economics 33: 401-25. [CrossRef]

Feldmann, Dorothy A., and David L. Schwarzkopf. 2003. The effect of institutional ownership on board and audit committee composition. Review of Accounting and Finance 2: 87-109. [CrossRef]

Fracassi, Cesare, and Geoffrey Tate. 2012. External networking and internal firm governance. The Journal of Finance 67: 153-94. [CrossRef]

Guedj, Ilan, and Amir Barnea. 2009. Director Networks. EFA 2007 Ljubljana Meetings Paper. Available online: https:/ / ssrn.com/abstract=966555 (accessed on 28 September 2016).

Guner, Burak A., Ulrike Malmendier, and Geoffrey A. Tate. 2008. Financial Expertise of Directors. Journal of Financial Economics 88: 323-54. [CrossRef]

Hallock, Kevin F. 1997. Reciprocally interlocking boards of directors and executive compensation. Journal of Financial and Quantitative Analysis 32: 331-44. [CrossRef] 
Healy, Paul M. 1985. The effect of bonus schemes on accounting decisions. Journal of Accounting and Economics 7: 85-107. [CrossRef]

Healy, Paul M., and James M. Wahlen. 1999. A Review of the Earnings Management Literature and Its Implications for Standard Setting. Accounting Horizons 13: 3653-83. [CrossRef]

Holthausen, Robert W., David F. Larcker, and Richard G. Sloan. 1995. Annual bonus schemes and the manipulation of earnings. Journal of Accounting and Economics 19: 29-74. [CrossRef]

Hwang, Byoung-Hyoun, and Seoyoung Kim. 2009. It pays to have friends. Journal of Financial Economics 93: 138-58. [CrossRef]

Hwang, Byoung-Hyoun, and Seoyoung Kim. 2010. Earnings Management and Social Ties. Available online: https: / / ssrn.com/abstract=1215962 (accessed on 28 November 2016).

Jaggi, Bikki, and Judy Tsui. 2007. Insider trading, earnings management and corporate governance: Empirical evidence based on Hong Kong firms. Journal of International Financial Management \& Accounting 18: 192-222.

Jensen, Michael C. 1993. The modern industrial revolution, exit, and the failure of internal control systems. The Journal of Finance 48: 831-80. [CrossRef]

Jensen, Michael C., and William H. Meckling. 1979. Theory of the Firm: Managerial Behavior, Agency Costs, and Ownership Structure. In Economics Social Institutions. Edited by Brunner Karl. Dordrecht: Springer, vol. 1, pp. 163-231.

Jiambalvo, James, Shivaram Rajgopal, and Mohan Venkatachalam. 2002. Institutional ownership and the extent to which stock prices reflect future earnings. Contemporary Accounting Research 19: 117-45. [CrossRef]

Jiraporn, Pornsit, and Peter J. DaDalt. 2009. Does founding family control affect earnings management? Applied Economics Letters 16: 113-19. [CrossRef]

Jones, Jennifer J. 1991. Earnings management during import relief investigations. Journal of Accounting Research 29: 193-228. [CrossRef]

Klein, April. 2002. Audit committee, board of director characteristics, and earnings management. Journal of Accounting and Economics 33: 375-400. [CrossRef]

Kothari, Sagar P., Andrew J. Leone, and Charles E. Wasley. 2005. Performance matched discretionary accrual measures. Journal of Accounting and Economics 39: 163-97. [CrossRef]

Krishnan, Jayanthi. 2005. Audit committee quality and internal control: An empirical analysis. The Accounting Review 80: 649-75. [CrossRef]

Krishnan, Gopal V., Krishnamurthy K. Raman, Ke Yang, and Wei Yu. 2011. CFO/CEO-Board Social Ties, Sarbanes-Oxley, and Earnings Management. Accounting Horizons 25: 537-57. [CrossRef]

Kuhnen, Camelia M. 2009. Business networks, corporate governance, and contracting in the mutual fund industry. The Journal of Finance 64: 2185-220. [CrossRef]

Larcker, David F., Scott A. Richardson, Andrew Seary, and Ayse Tuna. 2005. Back Door Links between Directors and Executive Compensation. Available online: https: / ssrn.com/abstract=671063 (accessed on 28 November 2016).

Leuz, Christian, Dhananjay Nanda, and Peter D. Wysocki. 2003. Earnings management and investor protection: An international comparison. Journal of Financial Economics 69: 505-27. [CrossRef]

Li, Chen, Yaping Wang, Liansheng Wu, and Jason Z. Xiao. 2016. Political Connections and Tax-Induced Earnings Management: Evidence from China. European Journal of Finance 22: 4134-31. [CrossRef]

Lim, Mable, Janice How, and Peter Verhoeven. 2014. Corporate ownership, corporate governance reform and timeliness of earnings: Malaysian evidence. Journal of Contemporary Accounting E Economics 10: 32-45.

Mills, Judson, and Margaret S. Clark. 1982. Exchange and communal relationships. Review of Personality and Social Psychology 3: 1211-44.

Nguyen, Bang Dang. 2012. Does the Rolodex matter? Corporate elite's small world and the effectiveness of boards of directors. Management Science 58: 236-52. [CrossRef]

Schmidt, Breno. 2015. Costs and benefits of friendly boards during mergers and acquisitions. Journal of Financial Economics 117: 424-47. [CrossRef]

Securities and Exchange Commission of Pakistan. 2012. The Code of Corporate Governance; Islamabad: Securities and Exchange Commission of Pakistan.

Uadiale, Olayinka Marte. 2012. Earnings management and corporate governance in Nigeria. Research Journal of Finance and Accounting 3: 1-10. 
Uzzi, Brian. 1996. The sources and consequences of embeddedness for the economic performance of organizations: The network effect. American Sociological Review 61: 674-98. [CrossRef]

Villalonga, Belén, and Raphael Amit. 2010. Family control of firms and industries. Financial Management 39: 863-904. [CrossRef]

Warfield, D. Terry, John J. Wild, and Kenneth L. Wild. 1995. Managerial ownership, accounting choices, and informativeness of earnings. Journal of Accounting and Economics 20: 61-91. [CrossRef]

Wei, Gang. 2007. Ownership structure, corporate governance and company performance in China. Asia Pacific Business Review 13: 519-45. [CrossRef]

Westphal, D. James, and Melissa E. Graebner. 2010. A matter of appearances: How corporate leaders manage the impressions of financial analysts about the conduct of their boards. Academy of Management Journal 53: 15-44. [CrossRef]

Young, N. Michael, Mike W. Peng, David Ahlstrom, Garry D. Bruton, and Yi Jiang. 2008. Corporate governance in emerging economies: A review of the principal-principal perspective. Journal of Management Studies 45: 196-220. [CrossRef]

Zajac, Edward J., and James D. Westphal. 1996. Director reputation, ceo/board power, and the dynamics of board interlocks. Academy of Management Journal 1: 254-58.

(c) 2017 by the authors. Licensee MDPI, Basel, Switzerland. This article is an open access article distributed under the terms and conditions of the Creative Commons Attribution (CC BY) license (http://creativecommons.org/licenses/by/4.0/). 